\title{
Valdir Medrado, o Educador
}

\author{
("On doit la verité aux morts" - Bossuet)
}

Morreu, no dia 15 deste mês (agosto de 2008), Valdir Cavalcante Medrado. E seria uma omissão muito grande se a sua morte ficasse sem registro, porque ele foi um dos maiores expoentes da anestesiologia brasileira. Teve militância associativa, foi presidente da SBA, criou a SBA volante, levando às capitais distantes do Brasil, numa época em que não se dispunha da internet (1973) nem mesmo de facilidades de telefonia a distância, a atualização necessária ao progresso da especialidade. Arautos da melhor categoria, a começar por ele próprio, foram escalados para discutir assuntos de sua competência nas capitais mais distantes do Brasil, quando os colegas desses lugares tiveram oportunidade de ouvir e discutir temas importantes com Álvaro Eugenio, Zairo Vieira, Carlos Parsloe, Danilo Duarte, GuiIherme Kurtz (pesquisador de farmacologia e autoridade em temas pertinentes à Anestesiologia, sobretudo bloqueadores neuromusculares). Valdir Medrado deu contribuições relevantes à nossa especialidade. Foi ele um dos pioneiros no Brasil do uso da peridural contínua para analgesia obstétrica (recurso apresentado por Philip Bromage, em 1960, no CBA de Goiânia) e foi ele também que trouxe para nós, da Duke University (seu ninho acadêmico nos EUA), o FNS, vaporizador "de bolso" para uso de halotano e metoxifluorano, e que passou a ser fabricado aqui pela indústria Grego/Dameca, sediada em Belo Horizonte. E foi ainda Valdir quem introduziu no Brasil, com estudos e observações em hospital universitário da Bahia, o Cl-581, a futura cetamina (Ketalar).

Mas é pouco relevante dizer o que Valdir fez, diante do que ele foi. Como assim? Ele foi um dos maiores educadores da Medicina brasileira no campo da Anestesiologia. Tinha paixão e amor pelo que fazia e uma extraordinária capacidade de motivação e convencimento. Não era um cientista, nem mesmo conferencista ou expositor destacado. Era um apaixonado pelo que fazia e conseguia motivar pessoas. Dele se disse, invocando Machado de Assis, que "não é a verdade que vence, quem vence é a convicção". Ele não se destacava por recursos dialéticos, mas tinha idéias e paixão, e isso, sim, era o seu argumento maior para persuadir e convencer. Valdir preparou mais de 200 anestesiologistas na Bahia. Deu dignidade à especialidade. E ele próprio foi um exemplo de nossa importância e valor na Medicina. Foi Diretor Médico de hospitais renomados de Salvador; fez parte do Conselho Regional e da Associação Bahiana de Medicina, onde idealizou e pôs em prática as jornadas da ABM no interior. Reativou e fez circular a Revista Médica da Bahia e saiu à frente na instalação de UTIs em Salvador. Freqüentou quase 40 congressos norte-americanos de Anestesiologia, sendo ele o primeiro a trazer de lá os Refreshers da ASA, publicação que era, na época, ouro em pó das atuali- dades em nossa área. E até há pouco tempo o Dr. Valdir era presença certa em todos os congressos brasileiros de Anestesiologia, tendo papel importante na organização dos que foram realizados na Bahia. E, para completar, ele não ficava ausente em nenhum encontro de anestesiologistas da SAEB, viajando pelo interior nos ônibus que levavam os participantes da capital, muitos deles seus ex-alunos, quase todos jovens, que encontravam no seu exemplo inspiração e entusiasmo para viver as experiências e alternativas da especialidade.

Mas Valdir não foi apenas médico e anestesiologista. Foi um apaixonado pela vida e um grande explorador cultural. Achava coisas onde outros não viam nada: artesanatos de Cachoeira, no recôncavo baiano; faianças portuguesas de Dias D'Avila; artistas anônimos de arte popular; coisas que ele mostrava a visitantes estrangeiros - bom cicerone que era - e que causava encantos em todos. (Errou quando levou Severinghaus, o famoso cientista da Anestesiologia mundial, ao primeiro e único shopping center da Bahia, na época, ouvindo dessa celebridade uma exclamação de desagrado, manifestada quase aos gritos: Why did you take me to this american shopping center?') Isso aborreceu Valdir, mas, num cartão enviado dos EUA, Severinghaus agradeceu a acolhida, dizendo que gostou de tudo na Bahia, least that shopping center, o que indica que ambos ficaram tocados pelo episódio.

Valdir deixou esposa, filhos e netos, e uma recordação positiva em todos os que foram tocados por sua influência e conheceram de perto a sua obstinação pelo trabalho e o exemplo de sua conduta ética na Medicina.

\section{Oliveiros Guanais}

\section{Valdir Medrado, the Professor}

("On doit la verité aux morts" - Bousset)

Valdir Cavalcante Medrado died on August 15, 2008. And it would be a tremendous omission if his death were not mentioned, since he was one of the greatest exponents of Brazilian anesthesiology. He was an active society member: he was president of the SBA, created the mobile SBA, which brought to distant state capitals, at a time the internet or even widespread long-distance calls were not available (1973), the necessary actualization for the development of anesthesiology. The best speakers, including Valdir Cavalcante Medrado, were chosen to discuss subjects of their specialty on in the most distant state capitals in Brazil, when colleagues in those cities had the opportunity to listen and discuss 
important subjects with Alvaro Eugênio, Zairo Vieira, Carlos Parsloe, Danilo Duarte, Guilherme Kurtz (pharmacology researcher and an authority on subjects pertaining to anesthesiology, especially neuromuscular blockers). Valdir Medrado gave important contributions to our subspecialty. He was one of the pioneers on the use of continuous epidural obstetric analgesia in Brazil (which was presented by Philip Bromage, in 1960, during the Brazilian Congress of Anesthesiology in Goiânia), and he also brought to us, from Duke University (his academic niche in the USA), the FNS, the "pocket" vaporizer for halothane and methoxyflurane, which was later manufactured by Grego/Dameca, a manufacturing plant in Belo Horizonte. And it was Valdir who introduced the C581, the future Ketamine (Ketalar), in Brazil, with studies and observations in a university hospital in Bahia.

But mentioning what he did is not relevant in face of who he was. What does it mean? He was one of the greatest professors of Brazilian Medicine in the field of Anesthesiology. He was passionate for what he did and had an extraordinary motivational and persuading capacity. He was not an outstanding scientist, speaker, or lecturer. He had passion for what he did and was able to motivate people. Quoting Machado de Assis**, "the truth does not win, conviction does". He was not known for his dialectic resources, but he had ideas and passion, and these were his tools to persuade and convince. Valdir prepared more than 200 anesthesiologists in Bahia. He brought dignity to our subspecialty. He was an example of the importance of anesthesiology in medicine. He was the Medical Director of renowned hospitals in Bahia; he was a member of the Regional Council and of the Medical Association of Bahia (ABM from the Por-

*TN: "to impinge the truth on the dead".

${ }^{* *} \mathrm{TN}$ : A Brazilian writer. tuguese), where he planned and introduced $A B M$ meetings in inner regions of the state. He reactivated and published the Medical Journal of Bahia, and pioneered the installation of ICUs in Salvador. He attended almost forty American anesthesiology congresses and brought the ASA Refreshers, considered the gold standard of our field, to Brazil. And, until recently, Dr. Valdir was present in all Brazilian Anesthesiology Congresses, and he had an important role in organizing those held in Bahia. And last, but not least, he was always present in every meeting of the SAEB, travelling throughout the state in the buses that took participants from the capital, many of them his former students, almost all of them young professionals who found on him inspiration and enthusiasm to live the experiences and alternatives of the specialty.

But Valdir was not just a physician and anesthesiologist. $\mathrm{He}$ was passionate about life and a great cultural explorer. $\mathrm{He}$ found treasures where other people didn't see anything: crafts from Cachoeira; Portuguese china from Dias D'avila; anonymous artists of the popular culture; things that he showed to visitors - he was a good cicerone - that marveled everyone (he made a mistake though by taking Severinghaus, a world famous anesthesiology scientist, to the first and only shopping center of Bahia at the time, who, almost shouting, expressed his displeasure: "Why did you bring me to this American shopping center?"). Valdir was deeply upset by what happened, but on a post card sent from the USA, Severinghaus thanked his warm welcome, saying he liked everything about Bahia, "least that shopping center", indicating that both of them were marked by the episode.

Valdir left behind a wife, children, and grandchildren, and a positive remembrance in everyone who were touched by his influence and witnessed his perseverance at work and the example of his ethical medical conduct.

\section{Oliveiros Guanais}

